\title{
Flow-Injection Spectrophotometric Determination of Bromate in Bottled Drinking Water Samples Using Chlorpromazine Reagent and a Liquid Waveguide Capillary Cell
}

\author{
Ildikó V. Tóth, * Inês C. Santos, ${ }^{* *}$ Cláudia F. M. Azevedo, ** Jorge F. S. Fernandes, ** \\ Ricardo N. M. J. PásCOA, ${ }^{* * *}$ Raquel B. R. Mesquita, ${ }^{* *, * * *}$ and António O. S. S. RANGeL ${ }^{* * \dagger}$ \\ *REQUIMTE, Laboratório de Química Aplicada, Departamento de Ciências Químicas, Faculdade de \\ Farmácia, Universidade do Porto, Rua Jorge Viterbo Ferreira, 228, 4050-313 Porto, Portugal \\ **CBQF-Centro de Biotecnologia e Química Fina, Escola Superior de Biotecnologia, Centro Regional do \\ Porto da Universidade Católica Portuguesa, Rua Dr. António Bernardino Almeida, 4200-072 Porto, \\ Portugal \\ ***Laboratory of Hydrobiology, Institute of Biomedical Sciences Abel Salazar (ICBAS) and Institute of Marine \\ Research (CIIMAR), Universidade do Porto, Rua de Jorge Viterbo Ferreira, 228, 4050-313 Porto, Portugal
}

\begin{abstract}
In this work, aiming to develop a simple, inexpensive method for the determination of low bromate levels in water samples, a liquid waveguide capillary cell (LWCC) was coupled to a FIA system. The long optical path $(100 \mathrm{~cm})$ of the LWCC was used to improve the sensitivity and the limit of detection without resorting to any off-line or in-line preconcentration processes. The spectrophotometric determination was based on the oxidation of chlorpromazine by bromate in an acidic medium, resulting in the formation of a colored radical product. Sulfamic acid was added to the reagent for minimizing the interference of nitrite, and a chelating ion exchange resin was used to remove major cationic interferences. The developed system allowed the determination of bromate within the range between $1-20 \mu \mathrm{g} \mathrm{L}^{-1}$ with a detection limit of $0.2 \mu \mathrm{g} \mathrm{\textrm {L } ^ { - 1 }}$.
\end{abstract}

(Received January 22, 2013; Accepted February 9, 2013; Published May 10, 2013)

\section{Introduction}

The presence of bromate in drinking water has been linked either to ozonation treatment ${ }^{1}$ which can produce the bromate anion as a by-product if the source water contains naturally occurring bromide, or to contamination of the hypochlorite feedstock $^{2,3}$ used for water disinfection. In bottled natural mineral water any disinfection treatment by whatever means is prohibited within the EU; however, for the separation of iron, manganese, arsenic and sulfur compounds from certain natural mineral water, the treatment with ozone-enriched air is allowed under strict control, and as long as it will not alter the essential composition of the water. ${ }^{4}$

Bromate has been indicated by both the World Health Organization $(\mathrm{WHO})^{5}$ and the U. S. Environmental Protection Agency (EPA) ${ }^{6}$ as a potential carcinogen, even at very low $\left(\mu \mathrm{g} \mathrm{L}^{-1}\right)$ levels. The estimated potential cancer risk is equivalent to 1 in $10^{4}$ for a lifetime exposure to drinking water containing bromate at $5 \mu \mathrm{g} \mathrm{L}^{-1}{ }^{6}$ A value of $10 \mu \mathrm{g} \mathrm{L}^{-1}$, established as the maximum contaminant level in water, is based on a compromise between the toxicity and analytical and technological possibilities of reaching low concentrations. ${ }^{5}$ Based on this parametric value, analytical methodologies capable to detect low levels of bromate $\left(<2 \mu \mathrm{g} \mathrm{L}^{-1}\right)$ are needed. Reference

† To whom correspondence should be addressed.

E-mail: arangel@ porto.ucp.pt methods for trace bromate detection include ion chromatographic separation coupled with suppressed conductivity detection, ${ }^{7}$ with post-column derivatization ${ }^{8,9}$ or with electrospray ionization tandem mass spectrometry. ${ }^{10}$ The analytical and instrumental difficulties include the high cost of the equipment and the complex sample preparation procedure used to measure bromate. Co-elution of bromate, with for example chloride, can occur, which leads to interferences in the analysis. To circumvent this problem, special separation techniques can be used, such as a high-capacity anion exchanger, or sample pretreatment. Bromate can then be measured using conductivity detection. But still, these methods are not always capable to reach the desired concentration levels. ${ }^{11}$

As potential alternatives, spectrophotometric methods were developed resorting to different redox reactions like the oxidation of phenothiazines, ${ }^{12,13}$ fuchsin, ${ }^{14}$ pyrogallol red, ${ }^{15}$ $o$-dianisidine ${ }^{16}$ or sulfonaphtholazoresorcinol. ${ }^{17}$ Phenothiazines (including chlorpromazine, prochlorperazine trifluoperazine, and thioridazine) show analytical characteristics that make them particularly interesting for implementation in a flow-based analytical method. The reaction is based on the formation of a colored radical cation; the reaction occurs in a highly acidic media, and the quantity of the excess acid has an important role in the extension of the reaction, as discussed in detail in previous publications. ${ }^{12,18-21}$ Therefore, the strictly controllable timing in a closed analytical circuit inherent to flow analysis systems ${ }^{22}$ can provide important contributions to the automation of this reaction. In a systematic study ${ }^{19}$ involving the family of 
phenothiazine reagents and the flow-injection strategy, chlorpromazine was found to be the most sensitive alternative, and provided the lowest detection limit. Previously developed flow analysis methods resorted to different flow techniques like multisyringe flow-injection analysis (MSFIA), ${ }^{18,19}$ or flow-injection analysis (FIA) ${ }^{21,23}$ reached in most cases detection limits that are competitive with the ion chromatographic alternatives for the determination of bromate in drinking-water samples. The selectivity of the determination, due to the redox nature of the reaction, is always an important aspect in these applications. The interfering effects of various ions were studied in detail, ${ }^{18,19}$ while taking into considerations the parametric values of the main components present in water for human consumption. However, the bromate analyte level at which the interfering effect was evaluated was, in most cases, above the maximum contaminant level ( 25 to $\left.250 \mu \mathrm{g} \mathrm{L}^{-1}\right)$.

The present work is aimed on the application of this reaction for the determination of bromate in bottled natural mineral water samples, while resorting to the increased sensitivity capillary flow cell. ${ }^{24}$ The incorporation of a long path-length liquid waveguide capillary cell (LWCC) into spectrometric detection systems can increase the optical path of the detector cell by orders of magnitude (up to $500 \mathrm{~cm}$ ), and therefore can increase the sensitivity of these, and consequently can reduce the detection limits. This increase can also increase the susceptibility to interferences; therefore, the effective elimination/masking of the interfering compounds requires careful optimization of the chemical parameters of the flow system. As an effective way to eliminate interferents in the higher concentration ranges, it might not be sufficiently selective in the low microgram per liter ranges. We intended in this work to evaluate the effect of possible interfering compounds at the actual maximum contaminant level for bromate (at $10 \mu \mathrm{g} \mathrm{L}^{-1}$ ). Moreover, the objective was to develop a simple flow-injection system capable to detect bromate at the desired level without resorting to any preconcentration procedure.

\section{Experimental}

\section{Reagents and chemicals}

All solutions were prepared with analytical-grade chemicals and boiled deionized water (specific conductance of less than $\left.0.1 \mu \mathrm{S} \mathrm{cm}^{-1}\right)$.

A chlorpromazine $(\mathrm{CPH})$ solution was daily prepared by dissolving $75 \mathrm{mg}$ of the solid and $0.97 \mathrm{~g}$ of sulfamic acid in $100 \mathrm{~mL}$ of water to final concentrations of $2.08 \mathrm{mmol} \mathrm{L}^{-1}$ chlorpromazine hydrochloride (Sigma Aldrich, St. Louis, MO) and $100 \mathrm{mmol} \mathrm{L}^{-1}$ sulfamic acid (Fluka-Sigma Aldrich, St. Louis, MO).

A $4 \mathrm{~mol} \mathrm{~L}^{-1}$ hydrochloric acid solution was prepared by appropriate dilution of the concentrated acid $(d=1.18 ; 37 \%)$.

A $1000 \mathrm{mg} \mathrm{L}^{-1}$ bromate standard solution (Ultra Scientific, LGC Standards, Barcelona, Spain) was used to prepare two stock solutions of $50.0 \mathrm{mg} \mathrm{L}^{-1}$ and $100 \mu \mathrm{g} \mathrm{L}^{-1}$ by successive dilutions. The working standards in the dynamic range of $0.05-2.00 \mathrm{mg} \mathrm{L}^{-1}$ were prepared by proper dilution of the $50.0 \mathrm{mg} \mathrm{L}^{-1}$ stock solution. The standards for the dynamic range of $1.00-20.0 \mu \mathrm{g} \mathrm{L}^{-1}$ were prepared from the $100 \mu \mathrm{g} \mathrm{L}^{-1}$ stock solution.

For dispersion studies, a $0.01 \mathrm{~mol} \mathrm{~L}^{-1}$ sodium borax solution and standard solutions of bromothymol blue were used; these solutions were prepared as recommended by Ruzicka and Hansen..$^{25}$

For the in-line elimination of metallic interferents, a chelating

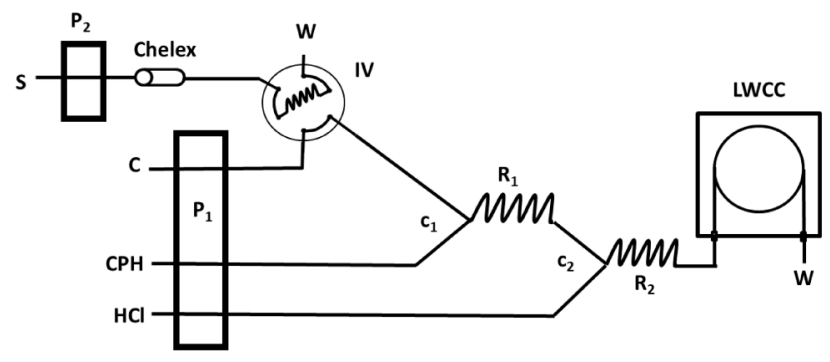

Fig. 1 FIA manifold for bromate determination in mineral drinking water samples: $\mathrm{P}_{\mathrm{i}}$, peristaltic pumps; IV, injection valve; $\mathrm{c}_{\mathrm{i}}$, confluences; $R_{1}$, reaction coil with $50 \mathrm{~cm} ; R_{2}$, reaction coil with $200 \mathrm{~cm} ; S$, sample or standard solutions; Chelex, column with Chelex 100 resin; C, carrier deionized water; $\mathrm{CPH}, 2.08 \mathrm{mmol} \mathrm{L}^{-1}$ chlorpromazine and $100 \mathrm{mmol} \mathrm{L}^{-1}$ sulfamic acid; $\mathrm{HCl}, 4 \mathrm{~mol} \mathrm{~L}^{-1}$ hydrochloric acid; LWCC, liquid waveguide capillary cell; $\mathrm{W}$, waste.

ion-exchange resin (Bio-Rad, Richmond, CA) was used. The Chelex 100 (200 - 400 mesh, sodium form) resin was suspended in a conditioning buffer. The buffer was obtained by dissolving $6.56 \mathrm{~g}$ of sodium acetate in water, adding $16 \mathrm{~mL}$ of concentrated acetic acid and diluting to $200 \mathrm{~mL}$ of water. The suspended resin was packed in PVC tubing with $2.29 \mathrm{~mm}$ i.d. and $2.5 \mathrm{~cm}$ length. A syringe was used to introduce the suspension into the column, and an ordinary dishwashing sponge was placed at both ends of the column to entrap the resin. Nitric acid $0.25 \mathrm{~mol} \mathrm{~L}^{-1}$ was used as an elution buffer to wash the resin; afterwards, the resin was reconditioned using the conditioning buffer. ${ }^{26}$

\section{Apparatus}

The flow-injection system comprised a Gilson Minipuls 3 peristaltic pump (Villiers-le-Bel, France) and a Rheodyne (Cotati, CA) Type 5020 six-port rotary injection valve. The flow channels were assembled with Gilson Tygon tubing for propulsion, and Teflon tubing from Omnifit $(0.8 \mathrm{~mm}$, Cambridge, UK) for the remaining conduits. Acrylic lab-made Y-shaped confluences were also used. The sample loop was $1 \mathrm{~m}$ long, corresponding to a volume of $500 \mu \mathrm{L}$. An additional peristaltic pump, Ismatec mini S-640 (Zurich, Switzerland), was used to fill the sample loop.

An Ocean Optics PC2000-ISA (Dunedin, FL) spectrophotometer equipped with a pair of $200 \mu \mathrm{m}$ fiber optic cables and a DH-2000 deuterium halogen light source (Top Sensor Systems, Eerbeek, The Netherlands) coupled to a liquid waveguide capillary cell (LWCC 2100, World Precision Instruments, Sarasota, FL) with a $1.0 \mathrm{~m}$ pathlength, $250 \mu \mathrm{L}$ inner volume and $550 \mu \mathrm{m}$ inner diameter was used as the detection system. Data acquisition was performed through the Avantes Software, Spectrawin 4.2, at $527 \mathrm{~nm}$.

For preliminary studies, a spectrophotometer (Novaspec II Visible Spectrophotometric), equipped with a Hellma (Müllheim/ Baden, Germany) 178.711-QS conventional flow cell (CFC, light path of $10 \mathrm{~mm}$; nominal inner volume of $30 \mu \mathrm{L}$ ) was used as detection system. The wavelength was set at $527 \mathrm{~nm} .{ }^{13}$ In this case, analytical signals were recorded using a Kipp \& Zonen BD 111 (Delft, Holland) chart recorder.

\section{Flow-injection manifold and procedure}

The developed flow-injection system for bromate determination in mineral drinking waters is depicted in Fig. 1.

With the injection valve (IV) in the loading position (depicted in Fig. 1) and with pump $\mathrm{P}_{2}$ activated, the sample passed through 
the cationic column (Chelex) before filling the sample loop, at a flow rate of $1.95 \mathrm{~mL} \mathrm{~min}^{-1}$.

Then, pump $\mathrm{P}_{2}$ was stopped and the IV position changed to the injection position; the sample was injected in the carrier stream (flow rate of $1.60 \mathrm{~mL} \mathrm{~min}^{-1}$ ). At the confluence $\left(\mathrm{c}_{1}\right)$ the sample merged with the color reagent, and mixing was promoted in reactor $\mathrm{R}_{1}$. This mixture merged along with the $\mathrm{HCl}$ solution (confluence $\mathrm{c}_{2}$ ). Afterwards, when the colored product reached the detector, the analytical signal was registered.

\section{Sample collection and characterization}

Bottled drinking water samples were acquired at local supermarkets (Porto, Portugal), and some physical-chemical parameters were assessed. The $\mathrm{pH}$ value was obtained with a Crison (Barcelona, Spain) potentiometer ( $\mathrm{pH}$ meter GLP 21) equipped with a combined electrode (Crison 52.02). The conductance was measured with a Crison conductimeter (Basic 30) equipped with a Crison conductivity cell (Crison 5292). The determination of the total organic carbon (TOC) was carried out using a Shimadzu TOC-VCSN (Tokyo, Japan) analyzer. The labeled sample types are listed within the electronic supplementary information.

\section{Results and Discussion}

Study of the flow system's physical and chemical parameters

Studies of some physical and chemical parameters were carried out using a conventional flow cell (CFC) instead of the LWCC.

The sample volume was the first parameter to be studied, and values of $75,250,500$ and $800 \mu \mathrm{L}$ were tested; as the sensitivity increased up to $500 \mu \mathrm{L}$, that was the chosen value. Then, a total flow rate of $2.80 \mathrm{~mL} \mathrm{~min}^{-1}\left(0.60 \mathrm{~mL} \mathrm{~min}^{-1}\right.$ for the $\mathrm{CPH}$ and $\mathrm{HCl}$ solution and $1.60 \mathrm{~mL} \mathrm{~min}^{-1}$ for the carrier) was chosen from studied values of $2.80,4.20$ and $5.60 \mathrm{~mL} \mathrm{~min}^{-1}$, since it also resulted in better sensitivity.

Both reaction coil lengths were studied so as ensure a good mixture between the sample and the $\mathrm{CPH}$ reagent (reaction coil $\mathrm{R}_{1}$ ), followed by the mixture with the hydrochloric acid (reaction coil $R_{2}$ ). Firstly, the situations for $R_{1}$ values of $0.5,1.0,1.5$ and $2.0 \mathrm{~m}$ were tested and, as the sensitivity decreased with increasing of the reactor length, because the dispersion of the sample limits the sensitivity, the $0.5 \mathrm{~m}$ length reactor was chosen. Then, the $\mathrm{R}_{2}$ length was studied; values of $0.6,1.0,1.6$ 2.0 and $2.6 \mathrm{~m}$ were tested. For the $2 \mathrm{~m}$ length, a significant sensitivity improvement was observed, so that was the chosen length. Since the reaction occurs under acidic conditions, $\mathrm{R}_{2}$ influences the sensitivity by increasing the reaction time available for the chlorpromazine oxidation by bromate in the acidic medium. ${ }^{12}$

The chlorpromazine concentration was studied in the range of $0.52-2.08 \mathrm{mmol} \mathrm{L}^{-1}$, and the best sensitivity was obtained for the chosen value of $2.08 \times 10^{-3} \mathrm{~mol} \mathrm{~L}^{-1}$.

As for the concentration of the hydrochloric acid, ${ }^{12,19,21}$ it was studied in the range of $1.6-4 \mathrm{~mol} \mathrm{~L}^{-1}$. The sensitivity increased with the increase of the concentration, so a $4 \mathrm{~mol} \mathrm{~L}^{-1}$ hydrochloric acid was chosen. Higher concentrations of $\mathrm{HCl}$ were not tested, since they could physically damage the flow system and flow-cell components.

Under these set conditions, a linear calibration curve was obtained in the dynamic range of $0.05-2.00 \mathrm{mg} \mathrm{L}^{-1}$.

\section{Sample volume}

With the purpose to reach a lower dynamic range, a liquid

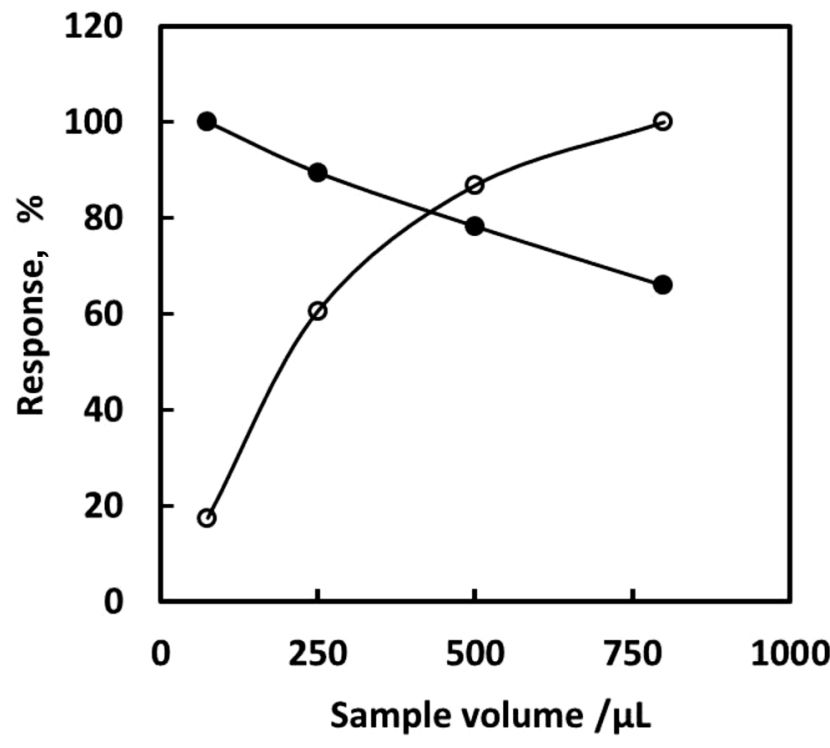

Fig. 2 Study of the influence of the sample volume on the sensitivity $(\bigcirc)$ and on the sampling rate $(\bullet)$. The response value (\%) was calculated with considering the highest value obtained for the sensitivity or sampling rate as $100 \%$.

waveguide capillary cell was then coupled to the FIA system.

Most of the previously set conditions for the CFC were also used with the LWCC. However, the effect of the sample volume was reassessed, because this parameter is among the most important ones affecting the dispersion in flow systems. ${ }^{25}$ In fact, with the LWCC an increase in the sample volume resulted in an increase of the sensitivity, but a decrease in the determination rate (Fig. 2). Thus, the chosen volume of $500 \mu \mathrm{L}$ was a compromise between the two parameters. These results are justified by the inner volume of the LWCC being $250 \mu \mathrm{L}$, so that the dispersion of the sample zone becomes less affected by the sample volume over this value.

Under these conditions, the sample dispersion values were assessed using bromothymol blue solutions, as recommended by Ruzicka and Hansen ${ }^{25}$ (BTB solutions were injected in place of the standard solutions, and a $0.01 \mathrm{~mol} \mathrm{~L}^{-1}$ Borax solution was used in place of the reagent and carrier solutions). Dispersion values of 2.5 for the LWCC and 1.6 for the CFC were obtained, indicating that the sample suffers a significantly higher dilution when the LWCC is used.

\section{Interference study}

The assessment of the interference of foreign species on the bromate determination is of utmost importance, since the determination in the first step is based on the formation of a colored radical compound that can undergo further oxidation induced by other oxidizing agents, or the free radical can lose another electron and form a colorless sulfoxide. ${ }^{12}$

An interference study was carried out for several possible interfering ions, and two ways of evaluating the possible interference were used.

Separate standard solutions containing the possible interfering species $\left(\mathrm{NO}_{2}^{-}, \mathrm{NO}_{3}^{-}, \mathrm{Fe}^{3+}, \mathrm{Cr}(\mathrm{III}), \mathrm{Cr}(\mathrm{VI}), \mathrm{ClO}_{2}^{-}\right.$and $\left.\mathrm{ClO}^{-}\right)$were prepared, and calibration curves were established using the developed FIA manifold (Table 1). This study is based on the linear response range of the different species, and not on the concentrations commonly found in water samples. Selectivity values towards these species were compared using the slope of 
Table 1 Tested possible interference species, the respective solid/standard solution used, the tested linear ranges and calculated slopes

\begin{tabular}{lcccc}
\hline $\begin{array}{c}\text { Tested } \\
\text { ion }\end{array}$ & $\begin{array}{c}\text { Prepared } \\
\text { from }\end{array}$ & $\begin{array}{c}\text { Linear range/ } \\
\mu \mathrm{mol} \mathrm{L} \mathrm{L}^{-1}\end{array}$ & $\begin{array}{c}\text { Slope/ } \\
\mathrm{L} \mu \mathrm{mol}^{-1}\end{array}$ & $\begin{array}{c}\text { Relative } \\
\text { sensitivity, } \\
\%\end{array}$ \\
\hline $\mathrm{BrO}_{3}^{-}$ & $\mathrm{BrO}_{3}^{-\mathrm{a}}$ & $0.0078-0.16$ & 2.17 & 100 \\
$\mathrm{NO}_{3}^{-}$ & $\mathrm{NaNO}_{3}$ & $400-8000$ & $8.5 \times 10^{-5}$ & $3.9 \times 10^{-3}$ \\
$\mathrm{NO}_{2}^{-}$ & $\mathrm{NaNO}_{2}$ & $0.10-2.00$ & 0.638 & 31 \\
$\mathrm{Fe}^{3+}$ & $\mathrm{Fe}^{3+\mathrm{a}}$ & $0.00036-3.6$ & 0.058 & 2.7 \\
$\mathrm{Cr}(\mathrm{III})$ & $\mathrm{Cr}(\mathrm{III})^{\mathrm{a}}$ & $0.096-0.96$ & 0.034 & 1.6 \\
$\mathrm{Cr}(\mathrm{VI})$ & $\mathrm{K}_{2} \mathrm{Cr}_{2} \mathrm{O}_{7}$ & $0.092-1.1$ & 1.68 & 77 \\
$\mathrm{ClO}_{2}^{-}$ & $\mathrm{NaClO}$ & $0.62-7.43$ & 0.098 & 4.5 \\
$\mathrm{ClO}^{-}$ & $\mathrm{Ca}(\mathrm{ClO})_{2}$ & $0.094-6.69$ & 0.245 & 11 \\
\hline
\end{tabular}

a. Prepared from AAS standard solutions.

Table 2 Interference values (\%) obtained for the different ions studied (concentration level of bromate at $10 \mu \mathrm{g} \mathrm{L}^{-1}$ )

\begin{tabular}{llcc}
\hline $\begin{array}{c}\text { Tested } \\
\text { ion }\end{array}$ & \multicolumn{1}{c}{$\begin{array}{c}\text { Solid/standard } \\
\text { solution }\end{array}$} & $\begin{array}{c}\text { Concentration/ } \\
\mathrm{mg} \mathrm{L}^{-1}\end{array}$ & $\begin{array}{c}\text { Interference, } \\
\%\end{array}$ \\
\hline $\mathrm{Ca}^{2+}$ & $\mathrm{Ca}\left(\mathrm{C}_{2} \mathrm{H}_{3} \mathrm{O}_{2}\right)_{2} \cdot \mathrm{H}_{2} \mathrm{O}$ & 100 & -4 \\
$\mathrm{Mg}^{2+}$ & $\mathrm{Mg}\left(\mathrm{NO}_{3}\right)_{2} \cdot 6 \mathrm{H}_{2} \mathrm{O}$ & 10 & 16 \\
$\mathrm{SO}_{4}^{2-}$ & $\mathrm{Na}_{2} \mathrm{SO}_{4}$ & 250 & -3 \\
$\mathrm{SO}_{3}{ }^{2-}$ & $\mathrm{Na}_{2} \mathrm{SO}_{3}$ & 250 & 7 \\
$\mathrm{Fe}^{3+}$ & $\mathrm{Fe}^{3+a}$ & 0.2 & 550 \\
$\left.\mathrm{Cr}^{2+} \mathrm{III}\right)$ & $\mathrm{Cr}(\mathrm{III})^{\mathrm{a}}$ & 0.05 & 9 \\
$\mathrm{ClO}_{2}{ }^{-}$ & $\mathrm{KClO}$ & 0.15 & 400 \\
$\mathrm{ClO}^{-}$ & $\mathrm{Ca}(\mathrm{ClO})_{2}$ & 4 & 650 \\
\hline
\end{tabular}

a. Prepared from AAS standard solutions.

the established calibration curves based on the molar concentration.

All of the slope values obtained for the different interfering species tested were lower, in most cases, by over tenfold, than the sensitivity obtained for the bromate calibration curve. An exception was observed for nitrite, which presented a sensitivity of about one third $(31 \%)$ of the sensitivity for bromate, and $\mathrm{Cr}(\mathrm{VI})$ with a sensitivity of $77 \%$.

An additional study was carried out by using sets of $10 \mu \mathrm{g} \mathrm{L}^{-1}$ bromate standards in the presence of possible interfering species. The levels used of these species considered the parametric values of the main components present in water for human consumption. The concentration of the interfering species and the interference percentages obtained are summarized in Table 2 .

The results obtained showed that some ions $\left(\mathrm{Fe}^{3+}, \mathrm{ClO}_{2}^{-}\right.$and $\mathrm{ClO}^{-}$), have a very significant interference. Among these, iron(III) shows a very different behavior when compared to the previous study. The results obtained indicate a synergistic, catalytic effect ${ }^{27,28}$ in the case that iron(III) and bromate coexist in the test solution. The results obtained for chlorite and hypochlorite are out of concern in this specific application, since it is not expected to find these ions in bottled drinking water. Although it was not as high, the interference of $\mathrm{Mg}^{2+}$ was also quite significant.

Minimization of nitrite interference. According to previous studies, ${ }^{18,19}$ nitrite interference can be eliminated by using sulfamic acid. Thus, a study was performed in order to assess whether sulfamic acid should be added to the chlorpromazine reagent, or to the $\mathrm{HCl}$ solution. Addition to the chlorpromazine reagent was chosen, because it resulted in a more efficient
Table 3 Interference values obtained for the different iron(III) standard

\begin{tabular}{cccc}
\hline $\begin{array}{c}{\left[\mathrm{BrO}_{3}^{-}\right] /} \\
\mu \mathrm{g} \mathrm{L}^{-1}\end{array}$ & $\begin{array}{c}{\left[\mathrm{Fe}^{3+}\right] /} \\
\mathrm{mg} \mathrm{L}^{-1}\end{array}$ & $\begin{array}{c}\text { Absorbance } \\
\text { value }\end{array}$ & $\begin{array}{c}\text { Interference, } \\
\%\end{array}$ \\
\hline 10 & 0.0 & $0.172 \pm 0.005$ & \\
10 & 0.2 & $0.178 \pm 0.005$ & 4 \\
10 & 0.6 & $0.172 \pm 0.005$ & 0 \\
10 & 1.0 & $0.188 \pm 0.006$ & 10 \\
\hline
\end{tabular}

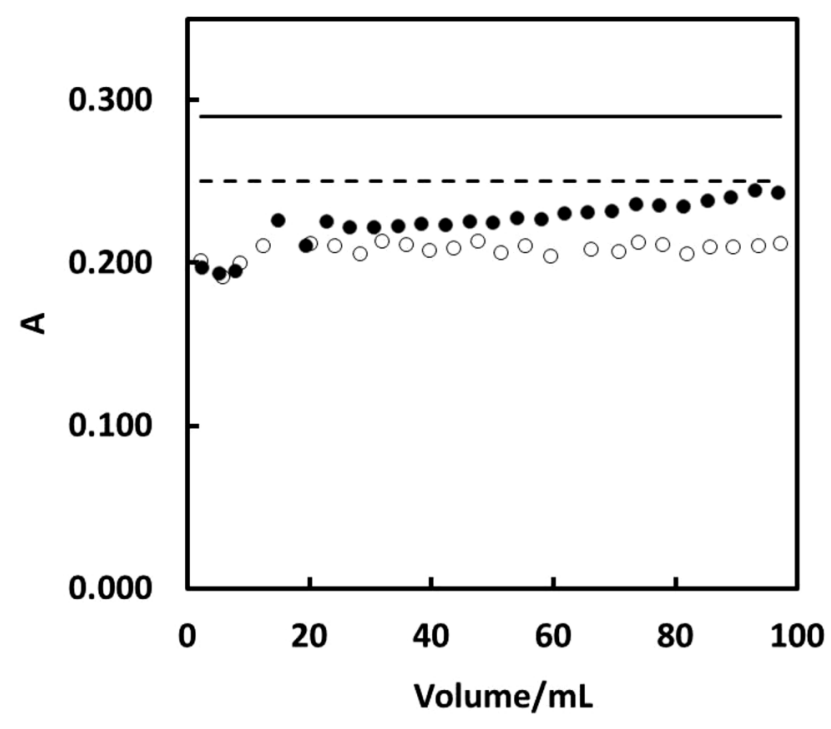

Fig. 3 Study of the breakthrough volume: $(\bullet)$ bromate concentration of $10 \mu \mathrm{g} \mathrm{L}^{-1}$ with $10 \mathrm{mg} \mathrm{L}^{-1}$ of $\mathrm{Mg}^{2+}$ and $\mathrm{Ca}^{2+}$ and $0.6 \mathrm{mg} \mathrm{L}^{-1} \mathrm{Fe}^{3+}$; (○) bromate concentration of $10 \mu \mathrm{g} \mathrm{L}^{-1}$ with $0.6 \mathrm{mg} \mathrm{L}^{-1} \mathrm{Fe}^{3+}$. The solid and dashed horizontal lines indicate the expected absorbance value at $10 \%$ and at $5 \%$ breakthrough of $\mathrm{Fe}^{3+}$, respectively.

minimization of nitrite interference. Also, a sulfamic acid concentration of $100 \mathrm{mmol} \mathrm{L}^{-1}$ was sufficient to minimize the nitrite interference up to a concentration of $2 \mu \mathrm{mol} \mathrm{L} \mathrm{L}^{-1}$, a value expected in drinking water.

Minimization of iron(III) interference. In order to minimize the interference from iron(III), a chelating ion-exchange resin (Chelex 100) column was included in the manifold before the injection valve. Under these conditions, when the sample was loaded into the sample loop it was pumped through the Chelex column. In order to assess the efficiency of the Chelex column, several $10 \mu \mathrm{g} \mathrm{L}^{-1}$ bromate standards were prepared with different concentrations of iron(III): the previously tested $0.2 \mathrm{mg} \mathrm{L}^{-1}$ and higher (up to $1 \mathrm{mg} \mathrm{L}^{-1}$ ), and the interference percentage calculated (Table 3 ).

The obtained results show a significant decrease in the percentage of interference from the previous 550 to $4 \%$. Thus, the iron(III) interference was effectively minimized by using the cationic resin, which has a capability to also retain other probable interfering cations, namely $\mathrm{Mg}^{2+}$.

Resin saturation experiments. In the proposed flow configuration, the saturation of the Chelex column is a crucial parameter to consider. The column should provide an efficient sample clean-up, and preferably no regeneration should be needed for at least a $100 \mathrm{~mL}$ sample volume. The limit (volume of the sample passing through the column), corresponds to the point where a breakthrough effect can be noticed. In the present case, a breakthrough can be recognized when the increase in the 
peak height reaches a value corresponding to the 5 or $10 \%$ of the expected analytical signal for the interfering ion.

Thus, in order to experimentally determine the breakthrough volume, a $10 \mu \mathrm{g} \mathrm{L}^{-1}$ standard bromate solution containing $10 \mathrm{mg} \mathrm{L}^{-1}$ of $\mathrm{Mg}^{2+}$ and $\mathrm{Ca}^{2+}$ and $0.6 \mathrm{mg} \mathrm{L}^{-1} \mathrm{Fe}^{3+}$ was prepared. Afterwards, the solution was continuously passed through the Chelex 100 column and injected in the system every $2 \mathrm{~min}$. The absorbance values were registered; and the obtained results can be seen in Fig. 3. A slight increase in the absorbance value can be noticed when the mixture contains $\mathrm{Mg}^{2+}, \mathrm{Ca}^{2+}$ and $\mathrm{Fe}^{3+}$ simultaneously with bromate. Nevertheless, only at around $100 \mathrm{~mL}$ of solution passing through the column does the signal reach the limit of the $5 \%$.

To find the concentration of $0.6 \mathrm{mg} \mathrm{L}^{-1}$ iron(III) in bottled

Table 4 Features of the developed FI system for bromate determination with a CFC and a LWCC

\begin{tabular}{ccccc}
\hline $\begin{array}{c}\text { Flow } \\
\text { cell }\end{array}$ & $\begin{array}{c}\text { Dynamic } \\
\text { range/ } \mu \mathrm{g} \mathrm{L}^{-1}\end{array}$ & Typical calibration curve & $\begin{array}{c}\mathrm{LOD}^{\mathrm{b}} / \\
\mu \mathrm{g} \mathrm{L}^{-1}\end{array}$ & $\begin{array}{c}\mathrm{LOQ}^{\mathrm{c}} \\
\mu \mathrm{g} \mathrm{L}^{-1}\end{array}$ \\
\hline CFC & $50-2000$ & $\begin{array}{c}A=0.1123( \pm 0.0025) \mathrm{mg} \\
\mathrm{BrO}_{3}-\mathrm{L}^{-1}+0.0050( \pm 0.0005)\end{array}$ & 15 & 50 \\
LWCC & $1.00-20.0 \quad \begin{array}{c}A=0.0183( \pm 0.0013) \mu \mathrm{g} \\
\mathrm{BrO}_{3}-\mathrm{L}^{-1}-0.013( \pm 0.011)\end{array}$ & 0.2 & 0.9 \\
\hline
\end{tabular}

a. Values between brackets correspond to the standard deviation of the equation parameters (CFC, $n=3$; LWCC, $n=8$ ).

b. Limit of detection.

c. Limit of quantification. water is in fact unrealistic, but performing the assay under these

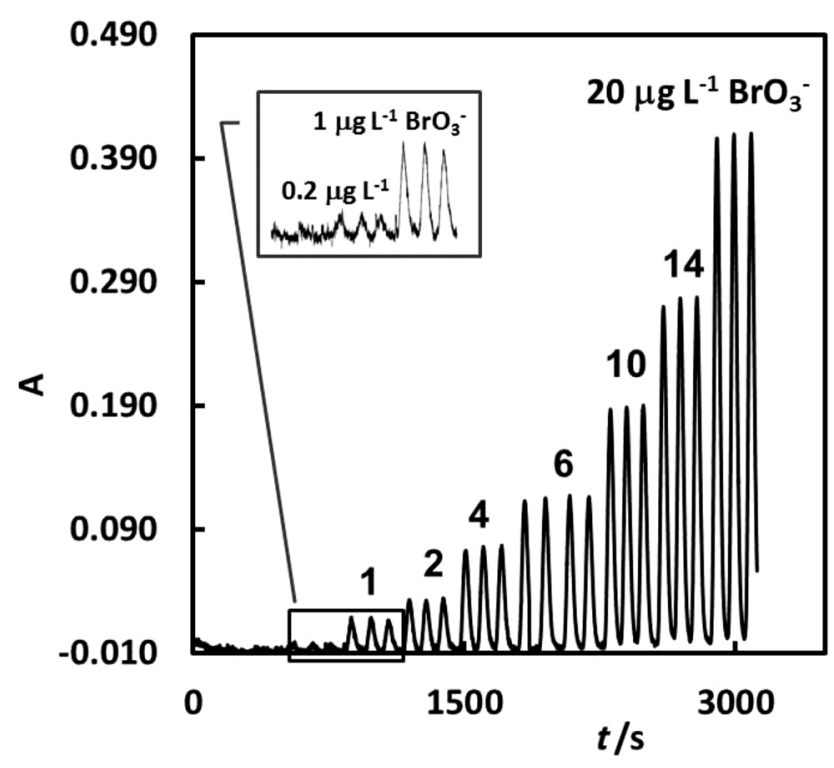

Fig. 4 Flow-injection register corresponding to injection of bromate working standard solutions in the range of 1 to $20 \mu \mathrm{g} \mathrm{L}{ }^{-1}$ in triplicate, using the developed flow-injection system with a liquid waveguide capillary cell. The amplified inset on the figure shows the baseline noise level and the peaks corresponding to a solution containing bromate at the level of the detection limit $\left(0.2 \mu \mathrm{g} \mathrm{L} \mathrm{L}^{-1}\right)$.

Table 5 Recovery percentages obtained with the developed FI system for the bromate determination in spiked natural mineral water ${ }^{4}$ samples

\begin{tabular}{|c|c|c|c|c|c|c|c|}
\hline Sample ID & $\mathrm{pH}$ & $\mathrm{G} / \mu \mathrm{S} \mathrm{cm}-1$ & $\begin{array}{c}\mathrm{TOC} / \\
\mathrm{mg} \mathrm{L}^{-1} \pm \mathrm{SD}\end{array}$ & $\begin{array}{c}\text { Initial/ } / \mu \mathrm{g} \\
\mathrm{BrO}_{3}^{-} \mathrm{L}^{-1} \pm \mathrm{SD}\end{array}$ & $\begin{array}{l}\text { Added } / \mu \mathrm{g} \\
\mathrm{BrO}_{3}{ }^{-} \mathrm{L}^{-1}\end{array}$ & $\begin{array}{c}\text { Found } / \mu \mathrm{g} \\
\mathrm{BrO}_{3}^{-} \mathrm{L}^{-1} \pm \mathrm{SD}\end{array}$ & $\begin{array}{l}\text { Recovery, } \\
\% \pm \text { SD }\end{array}$ \\
\hline \multirow[t]{3}{*}{ NMW1 } & 6.77 & 33.4 & $0.536 \pm 0.01$ & $<\mathrm{LOD}$ & 2.5 & $2.87 \pm 0.09$ & $114 \pm 4$ \\
\hline & & & & & 5 & $5.02 \pm 0.03$ & $101 \pm 1$ \\
\hline & & & & & 10 & $9.98 \pm 0.16$ & $99.8 \pm 1.6$ \\
\hline \multirow[t]{3}{*}{ NMW2 } & 4.95 & 40 & $0.182 \pm 0.03$ & $2.43 \pm 0.12$ & 2.5 & $4.68 \pm 0.04$ & $90.0 \pm 1.7$ \\
\hline & & & & & 5 & $7.17 \pm 0.1$ & $94.8 \pm 2.0$ \\
\hline & & & & & 10 & $12.5 \pm 0.2$ & $100 \pm 2$ \\
\hline \multirow[t]{3}{*}{ NMW3 } & 6.81 & 50.1 & $0.327 \pm 0.01$ & $1.61 \pm 0.11$ & 2.5 & $3.91 \pm 0.12$ & $92.3 \pm 4.9$ \\
\hline & & & & & 5 & $6.31 \pm 0.32$ & $94.1 \pm 6.5$ \\
\hline & & & & & 10 & $11.6 \pm 0.3$ & $99.6 \pm 3.4$ \\
\hline \multirow[t]{3}{*}{ NMW4 } & 6.64 & 301 & $0.238 \pm 0.01$ & $6.12 \pm 0.11$ & 2.5 & $8.42 \pm 0.19$ & $92.1 \pm 7.6$ \\
\hline & & & & & 5 & $11.2 \pm 0.29$ & $102 \pm 5.7$ \\
\hline & & & & & 10 & $16.4 \pm 0.3$ & $103 \pm 2.5$ \\
\hline \multirow[t]{3}{*}{ NMW5 } & 7.41 & 534 & $<0.050$ & $<\mathrm{LOD}$ & 2.5 & $2.49 \pm 0.08$ & $99.7 \pm 3.1$ \\
\hline & & & & & 5 & $5.1 \pm 0.15$ & $102 \pm 3$ \\
\hline & & & & & 10 & $10.2 \pm 0.1$ & $102 \pm 1$ \\
\hline \multirow[t]{3}{*}{ NMW6 } & 6.15 & 47.6 & $0.158 \pm 0.00$ & $<\mathrm{LOD}$ & 2.5 & $2.42 \pm 0.14$ & $96.9 \pm 5.4$ \\
\hline & & & & & 5 & $4.59 \pm 0.21$ & $91.8 \pm 4.2$ \\
\hline & & & & & 10 & $9.7 \pm 0.1$ & $97.0 \pm 0.9$ \\
\hline \multirow[t]{3}{*}{ NMW7 } & 6.73 & 93.1 & $<0.050$ & $2.04 \pm 0.13$ & 2.5 & $4.61 \pm 0.25$ & $103 \pm 17$ \\
\hline & & & & & 5 & $7.42 \pm 0.05$ & $108 \pm 5$ \\
\hline & & & & & 10 & $12.8 \pm 0.1$ & $108 \pm 1$ \\
\hline \multirow[t]{3}{*}{ NMW8 } & 5.91 & 94.6 & $0.123 \pm 0.02$ & $2.44 \pm 0.01$ & 2.5 & $5.53 \pm 0.12$ & $124 \pm 1$ \\
\hline & & & & & 5 & $7.57 \pm 0.37$ & $103 \pm 1$ \\
\hline & & & & & 10 & $12.7 \pm 0.1$ & $103 \pm 2$ \\
\hline
\end{tabular}


Table 6 Recovery percentages obtained with the developed FI system for the bromate determination in spiked bottled water samples

\begin{tabular}{|c|c|c|c|c|c|c|c|}
\hline Sample ID & $\mathrm{pH}$ & $\mathrm{G} / \mu \mathrm{S} \mathrm{cm}-1$ & $\begin{array}{c}\mathrm{TOC} / \\
\mathrm{mg} \mathrm{L}^{-1} \pm \mathrm{SD}\end{array}$ & $\begin{array}{c}\text { Initial/ } / \mu \mathrm{g} \\
\mathrm{BrO}_{3}^{-} \mathrm{L}^{-1} \pm \mathrm{SD}\end{array}$ & $\begin{array}{l}\text { Added/ } / \mu \mathrm{g} \\
\mathrm{BrO}_{3}{ }^{-} \mathrm{L}^{-1}\end{array}$ & $\begin{array}{c}\text { Found } / \mu \mathrm{g} \\
\mathrm{BrO}_{3}^{-} \mathrm{L}^{-1} \pm \mathrm{SD}\end{array}$ & $\begin{array}{l}\text { Recovery } \\
\% \pm \mathrm{SD}\end{array}$ \\
\hline \multirow[t]{3}{*}{ BW1 } & 6.86 & 29.5 & $0.099 \pm 0.01$ & $<\mathrm{LOD}$ & 2.5 & $2.44 \pm 0.02$ & $97.7 \pm 0.9$ \\
\hline & & & & & 5 & $4.55 \pm 0.16$ & $91.0 \pm 3.2$ \\
\hline & & & & & 10 & $9.6 \pm 0.1$ & $95.5 \pm 0.9$ \\
\hline \multirow[t]{3}{*}{ BW2 } & 7.44 & 108.2 & $0.224 \pm 0.02$ & $3.55 \pm 0.13$ & 2.5 & $6.01 \pm 0.13$ & $98.5 \pm 5$ \\
\hline & & & & & 5 & $8.58 \pm 0.1$ & $101 \pm 2$ \\
\hline & & & & & 10 & $13.4 \pm 0.9$ & $99.0 \pm 8.9$ \\
\hline \multirow[t]{3}{*}{ BW3 } & 7.3 & 61 & $0.383 \pm 0.01$ & $1.53 \pm 0.11$ & 2.5 & $4.27 \pm 0.23$ & $110 \pm 6$ \\
\hline & & & & & 5 & $6.58 \pm 0.05$ & $101 \pm 2$ \\
\hline & & & & & 10 & $11.9 \pm 0.2$ & $104 \pm 2$ \\
\hline \multirow[t]{3}{*}{ BW4 } & 6.77 & 44.6 & $0.241 \pm 0.00$ & $<\mathrm{LOD}$ & 2.5 & $2.55 \pm 0.12$ & $102 \pm 5$ \\
\hline & & & & & 5 & $4.94 \pm 0.06$ & $98.9 \pm 1.2$ \\
\hline & & & & & 10 & $9.8 \pm 0.1$ & $97.7 \pm 0.9$ \\
\hline \multirow[t]{3}{*}{ BW5 } & 5.54 & 51.4 & $<0.050$ & $<\mathrm{LOD}$ & 2.5 & $2.94 \pm 0.39$ & $118 \pm 13$ \\
\hline & & & & & 5 & $4.97 \pm 0.48$ & $99.3 \pm 6.8$ \\
\hline & & & & & 10 & $10.3 \pm 0.1$ & $104 \pm 0.6$ \\
\hline \multirow[t]{3}{*}{ BW6 } & 7.02 & 94.5 & $0.166 \pm 0.01$ & $<\mathrm{LOQ}(0.76) \pm 0.06$ & 2.5 & $3.23 \pm 0.19$ & $98.9 \pm 7.4$ \\
\hline & & & & & 5 & $5.8 \pm 0.14$ & $101 \pm 3$ \\
\hline & & & & & 10 & $10.9 \pm 0$ & $102 \pm 0$ \\
\hline \multirow[t]{3}{*}{ BW7 } & 6.62 & 35.4 & $2.395 \pm 0.04$ & $<\mathrm{LOQ}(0.85) \pm 0.07$ & 2.5 & $3.27 \pm 0.05$ & $96.9 \pm 1.8$ \\
\hline & & & & & 5 & $5.83 \pm 0.02$ & $99.6 \pm 0.5$ \\
\hline & & & & & 10 & $10.3 \pm 0.6$ & $95.0 \pm 6$ \\
\hline \multirow[t]{3}{*}{ BW8 } & 7.29 & 69.7 & $0.511 \pm 0.01$ & $1.62 \pm 0.17$ & 2.5 & $3.93 \pm 0.32$ & $92.4 \pm 16.9$ \\
\hline & & & & & 5 & $6.17 \pm 0.22$ & $91.1 \pm 4.5$ \\
\hline & & & & & 10 & $11.3 \pm 0.1$ & $96.4 \pm 1.3$ \\
\hline \multirow[t]{3}{*}{ BW9 } & 6.7 & 47.5 & $<0.050$ & $<\mathrm{LOD}$ & 2.5 & $2.56 \pm 0.11$ & $102 \pm 1$ \\
\hline & & & & & 5 & $5.07 \pm 0.06$ & $101 \pm 1$ \\
\hline & & & & & 10 & $10.2 \pm 0.2$ & $102 \pm 2$ \\
\hline
\end{tabular}

G, conductivity; TOC, total organic carbon; SD, standard deviation.

conditions assures that by maintaining the sample volume under $100 \mathrm{~mL}$, iron and other possible interfering cations will be retained on the resin. Therefore, during sample analysis, only after this volume passing through the resin column, should the retained ions be eluted, and the resin should be regenerated. When calibration curves obtained with standard solutions passing through the Chelex column and by direct injection were compared, no significant difference was observed; therefore, regeneration of the resin column can be carried out simultaneously with the calibration procedure.

\section{Features of the flow system}

Although for applications to mineral drinking water products, the expected values required the use of the LWCC, the analytical characteristics of the flow system with both flow cells were assessed. Thus, a summary of the main analytical features (the dynamic concentration range, typical calibration curve, limits of detection (LOD) and quantification (LOQ)) is given in Table 4.

The typical calibration curve with the CFC corresponds to the mean slope and the intercept of three calibration curves with the respective standard deviation. As for the typical calibration curve with LWCC (Fig. 4), it corresponds to the mean slope and intercept of eight calibration curves in consecutive days with the respective standard deviation.

There is a positive ( $>60 \%$ ) deviation found in the sensitivity when compared to what is theoretically expected from the increase of the light path. This deviation cannot be attributed to dilution effects, since the dispersion of the sample is in fact higher in the LWCC, but it should be related to kinetic effects. The use of much lower concentrations of the analyte and identical conditions of the other reagents results in a higher excess of the reagent and in higher extension of the reaction. ${ }^{24}$

Detection and quantification limits were calculated as three and ten-times the standard deviation of ten consecutive injections of deionized water, according to IUPAC recommendations. ${ }^{29}$

The repeatability was assessed by calculating of the relative standard deviation, $\mathrm{RSD} \%\left(\left[\mathrm{BrO}_{3}{ }^{-}\right] \mu \mathrm{g} \mathrm{L}^{-1} \pm \mathrm{SD}\right)$ obtained by the mean of ten consecutive injections of drinking water and spiked drinking water samples: $1.6(3.37 \pm 0.05) ; 1.3(4.23 \pm$ $0.06) ; 0.5$ (10.68 \pm 0.05$) ; 0.4$ (18.97 \pm 0.07$)$.

The established operation parameters included an injection volume of $500 \mu \mathrm{L}$ and two reactor coils with lengths of 50 and $200 \mathrm{~cm}$. The set flow rates were $0.60 \mathrm{~mL} \mathrm{~min}^{-1}$ for the $\mathrm{CPH}$ solution and the $\mathrm{HCl}$ solution and $1.60 \mathrm{~mL} \mathrm{~min}^{-1}$ for the carrier resulting in overall consumption values per determination of: $0.576 \mathrm{mg}$ of $\mathrm{CPH}, 7.57 \mathrm{mg}$ of sulfamic acid, $113.8 \mathrm{mg}$ of $\mathrm{HCl}$ and a waste volume of $3.64 \mathrm{~mL}$. Under these conditions (and not considering the resin elution and regeneration procedure), a determination rate of $46 \mathrm{~h}^{-1}$ was obtained.

\section{Application to water samples}

To assess the accuracy, recovery tests were performed using bottled drinking water samples. To characterize the samples, the $\mathrm{pH}$, conductivity and total organic carbon (TOC) content 
were determined as previously described.

Samples were spiked with equal volumes $(250 \mu \mathrm{L})$ of three bromate stock solutions $\left(500,1000\right.$ and $\left.2000 \mu \mathrm{g} \mathrm{L}^{-1}\right)$ to a final volume of $50.00 \mathrm{~mL}$. The calculation of the recovery percentage was performed according to IUPAC recommendations, ${ }^{29,30}$ and the obtained values are presented in Tables 5 and 6 .

The average of the obtained recovery percentages was $100 \%$ with a standard deviation of $6 \%$. A statistical test ( $t$-test) was used to evaluate if the mean recovery value did significantly differ from $100 \%$ and for a $95 \%$ significance level the calculated $t$-value was 0.275 with a correspondent critical value of 2.311 . So, the recovery percentages values did not statistically differ from $100 \%$, thus indicating the absence of multiplicative matrix interferences.

\section{Conclusions}

The developed flow method allowed the fast and sensitive detection of bromate at concentration levels lower than what is presently required based on the parametric value of MCL $10 \mu \mathrm{g} \mathrm{L}^{-1}$, demonstrating in this way to be an advantageous alternative for the detection of bromate in bottled drinking water products. However, there is an important remark that should be made: the interference of chlorite and hypochlorite could not be avoided under the present conditions of the developed method. Therefore, application to tap-water samples, which were subjected to chlorination treatment, is not supported by the present method.

The determination of bromate at trace levels was possible due to application of the LWCC equipped detection system. Nevertheless, the application of the increased sensitivity detection method also called attention to the increased susceptibility of the used oxidation reduction reaction to various interferences, for example the synergistic effect of iron on this determination. It was demonstrated that the iron(III) interference can be effectively controlled by using a cation exchange resin column.

When compared to previously described methods ${ }^{18,19,21}$ for the same spectrophotometric determination, the proposed method provides a better limit of quantification: $0.9 \mu \mathrm{g} \mathrm{L}^{-1}$ versus the $3.4 \mu \mathrm{g} \mathrm{L}^{-1},{ }^{18} 21 \mu \mathrm{g} \mathrm{L}^{-1},{ }^{19}$ and $10 \mu \mathrm{g} \mathrm{L}^{-1}{ }^{21}$ with no need for off-line or in-line preconcentration treatments. Direct sample introduction contributes to obtaining good repeatability (RSD\% $<2 \%$ ) and reproducibility.

\section{Acknowledgements}

I. V. T. thanks FSE and Ministério da Ciência, Tecnologia e Ensino Superior (MCTES) for financial support through the POPH-QREN program. I. C. S. and R. B. R. M. thank to Fundação para a Ciência e a Tecnologia (FCT, Portugal) and Fundo Social Europeu (FSE) the grants SFRH/BD/76012/2011 and SFRH/BPD/41859/2007, respectively. R. N. M. J. P. acknowledges financial support from FCT through the grants SFRH/BD/30621/2006 and SFRH/BPD/81384/2011. The authors also thank to FCT for financial support through national funds on projects PEst-C/EQB/LA0006/2011 and PEst-C/EQB/ LA0016/2011.

\section{References}

1. S. W. Krasner, H. S. Weinberg, S. D. Richardson, S. J.
Pastor, R. Chinn, M. J. Sclimenti, G. D. Onstad, and A. D. Thruston, Environ. Sci. Technol., 2006, 40, 7175.

2. H. S. Weinberg, C. A. Delcomyn, and V. Unnam, Environ. Sci. Technol., 2003, 37, 3104.

3. S. Bouland, J. P. Duguet, and A. Montiel, Environ. Technol., 2005, 26, 121.

4. EU, "on Exploitation and marketing of natural mineral waters", 2009, DIRECTIVE 2009/54/EC.

5. WHO, "Bromate in drinking water", 2005, WHO/SDE/ $\mathrm{WSH} / 05.08 / 78$.

6. EPA, "Toxicological review of bromate", 2001, U. S. Environmental Protection Agency, EPA/635/R-01/002.

7. EPA, "Determination of bromate in drinking water using two-dimensional ion chromatography with suppressed conductivity detection", 2009, U. S. Environmental Protection Agency, EPA 815-B-09-014.

8. EPA, "Determination of inorganic oxyhalide disinfection by-products in drinking water using ion chromatography with the addition of a postcolumn reagent for trace bromate analysis", 2000, U. S. Environmental Protection Agency, EPA Method 317.0.

9. EPA, "Determination of inorganic oxyhalide disinfection by-products in drinking water using ion chromatography incorporating the addition of a suppressor acidified postcolumn reagent for trace bromate analysis", 2002, U. S. Environmental Protection Agency, EPA 815-R-03007.

10. EPA, "Determination of haloacetic acids, bromate, and dalapon in drinking water by ion chromatography electrospray ionization tandem mass spectrometry (IC-ESIMS/MS)", 2009, U. S. Environmental Protection Agency, EPA 815-B-09-012.

11. H. P. Wagner, B. V. Pepich, D. P. Hautman, and D. J. Munch, J. Chromatogr., A, 2000, 882, 309.

12. H. Puzanowska-Tarasiewicz, J. Karpińka, A. Kojło, B. Starczewska, and E. Wołyniec, Chem. Anal., 2003, 48, 181.

13. S. Farrell, J. F. Joa, and G. E. Pacey, Anal. Chim. Acta, 1995, 313, 121.

14. L. Romele and M. Achilli, Analyst, 1998, 123, 291.

15. J. Medina-Escriche, A. Sevillano-Cabeza, M. MartinPenella, and M. Llobat-Estelles, Analyst, 1985, 110, 1467.

16. A. Alonso-Mateos, M. J. Almendral-Parra, and M. S. Fuentes-Prieto, Talanta, 2008, 76, 892.

17. A. Gahr, N. Huber, and R. Niessner, Microchim. Acta, 1998, 129, 281.

18. S. M. Oliveira, H. M. Oliveira, M. A. Segundo, A. O. S. S. Rangel, J. L. F. C. Lima, and V. Cerdà, Anal. Methods, 2012, 4, 1229.

19. S. M. Oliveira, M. A. Segundo, A. O. S. S. Rangel, J. L. F. C. Lima, and V. Cerdà, Anal. Lett., 2011, 44, 284.

20. M. G. Mitrakas, J. Anal. Chem., 2007, 62, 1055.

21. K. Uraisin, T. Takayanagi, D. Nacapricha, and S. Motomizu, Anal. Chim. Acta, 2006, 580, 68.

22. J. Ruzicka and E. H. Hansen, Anal. Chim. Acta, 1975, 78, 145 .

23. G. Gordon, B. Bubnis, D. Sweetin, and C.-Y. Kuo, Ozone Sci. Eng., 1994, 16, 79.

24. R. N. M. J. Páscoa, I. V. Tóth, and A. O. S. S. Rangel, Anal. Chim. Acta, 2012, 739, 1

25. J. Ruzicka and E. H. Hansen, "Flow Injection Analysis2nd edition", 1988, John Wiley and Sons, New York.

26. R. B. R. Mesquita, S. M. V. Fernandes, and A. O. S. S. Rangel, Talanta, 2004, 62, 395.

27. T. Tomiyasu, H. Sakamoto, and N. Yonehara, Anal. Sci., 1996, 12, 243. 
28. T. Tomiyasu, H. Sakamoto, and N. Yonehara, Anal. Sci. 1996, 12,507 .

29. M. Thompson, S. L. R. Ellison, and R. Wood, Pure Appl.
Chem., 2002, 74, 835 .

30. D. T. Burns, K. Danzer, and A. Townshend, Pure Appl. Chem., 2002, 74, 2201. 